\title{
Hubungan Karakteristik Klinis dan Laboratoris Terhadap Kejadian Miokarditis Difteri pada Anak di RSUD Dr. Zainoel Abidin Banda Aceh
}

Tita Menawati Liansyah, Mulya Safri, Sulaiman Yusuf

Bagian Ilmu Kesehatan Anak Fakultas Kedokteran Universitas Syiah Kuala/RSUD Dr. Zainoel Abidin, Banda Aceh

Latar belakang. Difteri merupakan penyakit infeksi yang disebabkan oleh Corynebacterium diphtheriae. Komplikasi terberat penyakit ini yaitu terjadinya miokarditis yang dapat mengakibatkan kematian.

Tujuan. Mengetahui hubungan antara karakteristik klinis dan laboratoris terhadap kejadian miokarditis difteri pada anak di RSUDZA Banda Aceh.

Metode. Jenis penelitian ini adalah observasional analitik dengan pendekatan cross sectional yang menggunakan data rekam medik pasien difteri periode Januari 2017 hingga Desember 2019. Sampel 101 pasien difteri dengan metode purposive sampling. Analisis data menggunakan univariat dan bivariat dengan Chi-square test.

Hasil. Berdasarkan hasil analisis bivariat antara karakteristik klinis dengan terjadinya miokarditis difteri didapatkan hasil (CI=95\%; $\mathrm{p}<0,05)$ untuk stridor dan (CI=95\%; $>0,05)$ untuk variabel letak membran, demam, nyeri tenggorokan, suara parau, bull neck dan derajat difteri. Analisis antara karakteristik laboratoris (leukosit, Troponin I, CK-MB, SGOT dan SGPT) dengan terjadinya miokarditis difteri didapatkan hasil $(\mathrm{CI}=95 \% ; \mathrm{p}>0,05)$

Kesimpulan. Terdapat hubungan antara variabel karakteristik klinis, yaitu stridor dengan terjadinya miokarditis difteri. Sementara variabel lain, seperti letak membran, demam, nyeri tenggorokan, suara parau, bull neck dan derajat difteri tidak ada hubungan dengan terjadinya miokarditis difteri. Tidak ada hubungan antara variabel karakteristik laboratoris (leukosit, Troponin I, CK-MB, SGOT dan SGPT) dengan terjadinya miokarditis difteri pada anak di RSUDZA Banda Aceh. Sari Pediatri 2020;22(3):131-8

Kata kunci: miokarditis difteri, karakteristik klinis, laboratoris

\section{The Relationship of Clinical and Laboratory Characteristics to the Incidence of Diphtheria Myocarditis in Children at Dr. Zainoel Abidin Banda Aceh}

Tita Menawati Liansyah, Mulya Safri, Sulaiman Yusuf

Background. Diphtheria is an infectious disease caused by Corynebacterium diphtheriae. The most severe complication of this disease is the occurrence of myocarditis which can cause death.

Objective. To analyze the relationship of clinical and laboratory characteristics to the diphtheria myocarditis in children at RSUDZA Banda Aceh.

Method. Analytical observational research with cross-sectional design data collection was carried out through medical records from January 2017 to December 2019. The sample consisted of 101 diphtheriae patients taken using purposive sampling technique, according to inclusion and exclusion criteria. The dependent variable studied was diphtheria myocarditis. The independent variable studied was clinical and laboratory characteristics. Data were analyzed using chi-square, the $\mathrm{p}$-value $<0.05$ was considered as significant. Result. Based on the results of the bivariate analysis between clinical characteristics and the occurrence of diphtheria myocarditis, the results were $(\mathrm{CI}=95 \% ; \mathrm{p}<0.05)$ for stridor and $(\mathrm{CI}=95 \%$; $>0.05)$ for the variable location of the membrane, fever, sore throat, hoarseness, bull neck and degrees of diphtheria. Analysis between laboratory characteristics (leucocytes, Troponin I, CK-MB, SGOT, and SGPT) with the occurrence of diphtheria myocarditis obtained results (CI $=95 \% ; \mathrm{p}>0.05)$.

Conclusion. There was a relationship between clinical characteristic (stridor) with the occurrence of diphtheria myocarditis in children, while other variables, namely the location of the membrane, fever, sore throat, hoarseness, bull neck, and degree of diphtheria have no a relationship with the occurrence of diphtheria myocarditis in children at RSUDZA. There weren't relationship between laboratory characteristic variables (leucocytes, Troponin I, CK-MB, SGOT, SGPT) and the occurrence of diphtheria myocarditis in children at RSUDZA Banda Aceh. Sari Pediatri 2020;22(3):131-8

Keywords: diphtheria myocarditis, clinical characteristics, laboratory

Alamat korespondensi: Tita Menawati Liansyah. Departemen Ilmu Kesehatan Anak Fakultas Kedokteran Universitas Syiah Kuala/RSUDZA Lantai 2, Jl. Tgk. Daud Beureueh No. 108 Banda Aceh, 24415. Email: ppds1ikafk@gmail.com 


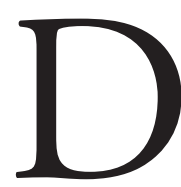
ifteri merupakan penyakit infeksi yang disebabkan oleh bakteri Corynebacterium diphtheriae (C. diphtheriae). Kasus penyakit difteri saat ini masih menjadi Kejadian Luar Biasa (KLB) dan menyebabkan kematian. Data Badan Kesehatan Dunia WHO hingga periode September 2018, diketahui bahwa jumlah kejadian difteri di Indonesia menempati urutan tertinggi kedua di dunia setelah India. ${ }^{1}$ Aceh merupakan provinsi peringkat kedua setelah Jawa Timur dengan kasus difteri terbanyak di Indonesia. Insiden difteri pada anak di Aceh semakin meningkat setiap tahunnya, berdasarkan data dari Dinas Kesehatan Aceh pada tahun 2016 terdapat 11 kasus dan meningkat menjadi 117 kasus pada tahun 2017, kemudian tahun 2018 terjadi peningkatan yang cukup signifikan sebesar 200 kasus difteri dan pada tahun 2019 terjadi penurunan menjadi 129 kasus. $^{2}$

Arya $\mathrm{dkk}^{3}$ menyatakan bahwa miokarditis merupakan komplikasi yang paling sering terjadi pada difteri. Miokarditis difteri merupakan suatu penyakit inflamasi dari miokardium yang disebabkan oleh toksin $C$. diphtheriae. Toksin yang poten secara berlebihan akan diabsorbsi ke dalam sirkulasi dan merusak organ sehingga dapat sebabkan kematian. ${ }^{4,5}$ Terjadinya miokarditis difteri dipengaruhi oleh virulensi kuman (biasanya tipe mitis akan menyebabkan miokarditis), lokalisasi kuman (lebih sering terjadi pada tonsilitis difteri yang disertai bull neck), imunisasi difteri yang tidak lengkap dan pemberian steroid di awal perjalanan penyakit yang digunakan untuk mencegah atau mengurangi derajat komplikasi pada sistem kardiovaskular. Akan tetapi hal tersebut belum dapat dibuktikan secara nyata. ${ }^{6}$

Insiden miokarditis difteri ini sulit dikemukakan dengan tepat karena laporan, baik dari negara maju maupun negara berkembang, sangat bervariasi. Penelitian di Swedia oleh Skogmar dan Tham ${ }^{7}$ menyatakan bahwa komplikasi terjadinya miokarditis terjadi sekitar $10-20 \%$ pada pasien difteri. Insiden terjadinya miokarditis difteri di India berkisar antara 16-66\%. ${ }^{5}$ Sementara itu Besa $\mathrm{dkk}^{8}$ yang melakukan penelitian mengenai difteri di Nigeria menyatakan bahwa insiden terjadinya miokarditis sebesar 25\%.

Eksotoksin difteri bermanifestasi pada jantung berupa miokarditis yang dapat terjadi, baik pada difteria ringan maupun berat, dan biasanya terjadi pada pasien yang terlambat mendapatkan pengobatan antitoksin. Pada umumnya, penyulit terjadi pada minggu ke-2, tetapi dapat ditemui pada minggu pertama atau baru terjadi pada minggu ke-6. Manifestasi miokarditis dapat berupa takikardia, suara jantung redup, terdengar bising jantung, atau aritmia. Bisa juga terjadi gagal jantung. Kelainan pemeriksaan elektrokardiogram dapat berupa elevasi segmen ST, perpanjangan interval PR, dan heart block. ${ }^{9}$

Luasnya variasi insiden miokarditis berkaitan dengan metode yang digunakan untuk mendiagnosis miokarditis, apakah menggunakan hasil pemeriksaan elektrokardiografi, biomarker jantung (troponin I, SGOT, SGPT, leukosit, CK-MB, c-reaktif protein), ekokardiografi, cardiovascular Magnetic Resonance Imaging, atau biopsi endomiokardial. ${ }^{5}$ Oleh sebab itu, perbedaan kriteria diagnosis dapat menyebabkan luasnya variasi insiden miokarditis pada difteri. Sebagian ahli menganggap bahwa $S-T$ depresi ataupun elevasi sebesar $1 \mathrm{~mm}$ sudah merupakan tanda miokarditis, namun sebagian lainnya mensyaratkan perubahan EKG yang lebih nyata, misalnya disritmia atau gangguan konduksi intraventrikuler. ${ }^{6}$ Tujuan penelitian ini untuk mengetahui hubungan antara karakteristik klinis dan laboratoris terhadap kejadian miokarditis difteri pada anak di RSUDZA Banda Aceh.

\section{Metode}

Rancangan penelitian ini adalah observasional analitik dengan studi potong lintang. Metode pengambilan sampel dengan non-probability sampling yaitu purposive sampling. Diperoleh 101 sampel yang memenuhi kriteria inklusi, yaitu pasien difteri yang berusia 1 bulan hingga 18 tahun yang tercatat dalam rekam medis yang dirawat di ruang isolasi periode Januari 2017 hingga Desember 2019. Kriteria eksklusi adalah rekam medis yang tidak memiliki data lengkap. Variabel dependen yaitu miokarditis difteri, sedangkan variabel independen adalah karakteristik klinis (letak membran, ada tidak-nya demam, nyeri tenggorokan, suara parau, stridor, bull neck dan derajat difteri) dan karakteristik laboratoris (kadar leukosit, troponin I, CKMB, SGOT, SGPT dan hasil kultur). Analisis data dengan analisis univariat dan bivariat yang menggunakan uji Chi-square test, data bermakna bila $\mathrm{p}<0,05$. Pengolahan data dilakukan dengan program komputer (SPSS 24.0 for windows).

Penelitian ini telah memperoleh kelaikan etik dari Komite Etik Fakultas Kedokteran Universitas Syiah Kuala Banda Aceh dengan nomor registrasi 005/ EA/ FK-RSUDZA/ 2020, pada tanggal 8 Januari 2020. 


\section{Hasil}

Subyek penelitian didapatkan 101 orang dari 106 pasien difteri yang memenuhi kriteria inklusi. Karakteristik subyek penelitian berdasarkan banyaknya kasus difteri yang dibedakan berdasarkan jenis kelamin, usia, status gizi, status imunisasi, lama sakit sebelum masuk rumah sakit, dan komplikasi. Data karakteristik subyek tertera pada Tabel 1 .

Berdasarkan karakteristik subyek penelitian diketahui bahwa jenis kelamin perempuan lebih banyak dari pada laki-laki. Insiden tertinggi terjadinya difteri pada usia lima hingga sembilan tahun. Sementara usia di bawah satu tahun merupakan insiden terendah. Rerata terjadinya penyakit ini adalah usia 9,5 tahun. Status gizi normal, lama sakit di atas tiga hari sebelum masuk rumah sakit, dan status imunisasi difteri yang tidak lengkap merupakan salah satu karakteristik subyek penelitian dengan persentase terbesar. Sebaliknya, anak dengan riwayat imunisasi lengkap memberikan persentase yang paling sedikit untuk terjadinya difteri. Tabel satu juga menyajikan data bahwa komplikasi tersering pada penderita difteri yaitu terjadinya miokarditis (71,3\%) dibandingkan dengan terjadinya acute kidney injury AKI dan obstruksi saluran nafas, sementara pasien difteri yang tidak memiliki komplikasi terdapat 17,8\%

Karakteristik klinis pasien yang diteliti meliputi letak membran, ada tidaknya demam, nyeri tenggorok, suara parau, stridor, bull neck dan derajat difteri tertera pada Tabel 2.

Karakteristik laboratoris meliputi kadar leukosit, troponin I, CKMB, SGOT, SGPT dan hasil kultur (Tabel 3).

Analisis bivariat dilakukan untuk mengetahui hubungan variabel karakteristik klinis dan laboratoris

\begin{tabular}{|c|c|c|c|c|}
\hline Karakteristik subyek & $\mathrm{N}$ & Persentase (\%) & $\bar{x}$ & SD \\
\hline \multicolumn{5}{|l|}{ Jenis kelamin } \\
\hline Laki-laki & 49 & 48,5 & & \\
\hline Perempuan & 52 & 51,5 & & \\
\hline Usia (tahun) & & & 9,5 & 4,6 \\
\hline$<1$ & 1 & 1 & & \\
\hline $1-4$ & 17 & 16,8 & & \\
\hline $5-9$ & 35 & 34,7 & & \\
\hline $10-14$ & 30 & 29,7 & & \\
\hline $15-18$ & 18 & 17,8 & & \\
\hline \multicolumn{5}{|l|}{ Status gizi } \\
\hline Normal & 44 & 43,6 & & \\
\hline Kurang & 41 & 40,6 & & \\
\hline Buruk & 0 & 0 & & \\
\hline Lebih & 11 & 10,8 & & \\
\hline Obesitas & 5 & 5 & & \\
\hline \multicolumn{5}{|l|}{ Status imunisasi (difteri) } \\
\hline Tidak pernah & 20 & 19.8 & & \\
\hline Tidak lengkap & 63 & 62.4 & & \\
\hline Lengkap & 18 & 17,8 & & \\
\hline \multicolumn{5}{|c|}{ Lama sakit sebelum masuk RS } \\
\hline$<3$ hari & 21 & 50 & & \\
\hline$>3$ hari & 80 & 6 & & \\
\hline \multicolumn{5}{|l|}{ Komplikasi } \\
\hline Miokarditis & 72 & 71.3 & & \\
\hline AKI & 9 & 8,9 & & \\
\hline Sumbatan jalan nafas & 2 & 2,0 & & \\
\hline Tidak ada & 18 & 17,8 & & \\
\hline
\end{tabular}


terhadap terjadinya miokarditis pada pasien difteri. Analisis data menggunakan uji chi-square dan tertera pada Tabel 4 dan 5 .

Tabel 2. Karakteristik klinis subyek penelitian

\begin{tabular}{lc}
\hline Karakteristik klinis & $\mathrm{n}(\%)$ \\
\hline Letak membran & \\
$\quad$ Tonsil unilateral & $33(32,7)$ \\
Tonsil bilateral & $45(44,6)$ \\
Faring & $23(22,8)$ \\
Nyeri tenggorok & $95(94,1)$ \\
Demam & $87(86,1)$ \\
Suara parau & $23(22,8)$ \\
Stridor & $28(27,7)$ \\
Bull neck & $13(12,9)$ \\
Derajat difteri & \\
$\quad$ Ringan & $41(40,6)$ \\
Sedang & $44(43,6)$ \\
Berat & $16(15,8)$ \\
\hline
\end{tabular}

Tabel 3. Karakteristik laboratoris subyek penelitian

\begin{tabular}{|c|c|c|c|}
\hline $\begin{array}{l}\text { Karakteristik } \\
\text { laboratoris }\end{array}$ & n (\%) & $\bar{x}$ & SD \\
\hline Leukosit $\left(/ \mathrm{mm}^{3}\right)$ & & $14.361 / \mathrm{mm}^{3}$ & 5,94 \\
\hline 5000-10.000 & $25(24,8)$ & & \\
\hline$>10.000$ & $76(75,2)$ & & \\
\hline Troponin I & & - & \\
\hline$<0,1$ & $18(17,8)$ & & \\
\hline $0,1-1,49$ & $3(3)$ & & \\
\hline Tidak diperiksa & $80(79,2)$ & & \\
\hline CK-MB $(\mu / \mathrm{L})$ & & 30,23 U/L & 8,35 \\
\hline$<24$ & $4(4)$ & & \\
\hline$>24$ & $17(16,8)$ & & \\
\hline Tidak diperiksa & $80(79,2)$ & & \\
\hline SGOT $(\mu / \mathrm{L})$ & & $45 \mu / \mathrm{L}$ & 25,78 \\
\hline$<31$ & $6(5,9)$ & & \\
\hline$>31$ & $8(7,9)$ & & \\
\hline Tidak diperiksa & $87(86,1)$ & & \\
\hline $\operatorname{SGPT}(\mu / \mathrm{L})$ & & $54 \mu / \mathrm{L}$ & \\
\hline$<34$ & $5(5)$ & & 43,52 \\
\hline$>34$ & $8(7,9)$ & & \\
\hline Tidak diperiksa & $88(87,1)$ & & \\
\hline \multicolumn{4}{|l|}{ Hasil kultur } \\
\hline Kultur positif & $34(33,8)$ & & \\
\hline Mitis & $13(38,2)$ & & \\
\hline Intermediat & $4(11,8)$ & & \\
\hline Gravis & $15(44,1)$ & & \\
\hline Non toksigenik & $2(5,9)$ & & \\
\hline Kultur negatif & $33(32,4)$ & & \\
\hline Tidak ada hasil & $34(33,8)$ & & \\
\hline
\end{tabular}

Tabel 4. Hubungan karakteristik klinis terhadap terjadinya miokarditis

\begin{tabular}{|c|c|c|c|}
\hline Variabel & $\begin{array}{c}\text { Miokarditis } \\
\text { difteri } \\
\text { n (\%) }\end{array}$ & $\begin{array}{c}\text { Difteri } \\
\text { tanpa } \\
\text { miokarditis } \\
\mathrm{n}(\%)\end{array}$ & $\mathrm{p}$ \\
\hline $\begin{array}{l}\text { Letak membran } \\
\text { Tonsil unilateral } \\
\text { Tonsil bilateral } \\
\text { Faring }\end{array}$ & $\begin{array}{l}22(66,7) \\
33(73,3) \\
17(73,9)\end{array}$ & $\begin{array}{c}11(33,3) \\
12(26,7) \\
6(26,1)\end{array}$ & 0,773 \\
\hline $\begin{array}{l}\text { Nyeri tenggorokan } \\
\text { Ada } \\
\text { Tidak }\end{array}$ & $\begin{array}{c}69(72,6) \\
3(50)\end{array}$ & $\begin{array}{c}26(27,3) \\
3(50)\end{array}$ & 0,47 \\
\hline $\begin{array}{l}\text { Demam } \\
\text { Ada } \\
\text { Tidak }\end{array}$ & $\begin{array}{c}63(72,4) \\
9(64,3)\end{array}$ & $\begin{array}{c}24(27,6) \\
5(35,7)\end{array}$ & 0,76 \\
\hline $\begin{array}{l}\text { Suara parau } \\
\text { Ada } \\
\text { Tidak }\end{array}$ & $\begin{array}{l}15(65,2) \\
57(73,1)\end{array}$ & $\begin{array}{c}8(34,8) \\
21(26,9)\end{array}$ & 0,638 \\
\hline $\begin{array}{l}\text { Stridor } \\
\text { Ada } \\
\text { Tidak }\end{array}$ & $\begin{array}{l}15(53,6) \\
57(78,1)\end{array}$ & $\begin{array}{l}13(46,4) \\
16(21,9)\end{array}$ & 0,028 \\
\hline $\begin{array}{l}\text { Bullneck } \\
\text { Ada } \\
\text { Tidak }\end{array}$ & $\begin{array}{l}12(92,3) \\
60(68,2)\end{array}$ & $\begin{array}{c}1(7,7) \\
28(31,8)\end{array}$ & 0,143 \\
\hline $\begin{array}{l}\text { Derajat difteri } \\
\text { Ringan } \\
\text { Sedang } \\
\text { Berat }\end{array}$ & $\begin{array}{l}32(78) \\
28(63,6) \\
12(75)\end{array}$ & $\begin{array}{c}9(22) \\
16(36,4) \\
29(28,7) \\
\end{array}$ & 0,320 \\
\hline
\end{tabular}

Tabel 5. Hubungan karakteristik laboratoris terhadap terjadinya miokarditis

\begin{tabular}{|c|c|c|c|}
\hline Variabel & $\begin{array}{l}\text { Miokarditis } \\
\text { difteri } \\
\mathrm{n}(\%)\end{array}$ & $\begin{array}{c}\text { Difteri tanpa } \\
\text { miokarditis } \\
\mathrm{n}(\%)\end{array}$ & $p$ \\
\hline $\begin{array}{l}\text { Leukosit }\left(/ \mathrm{mm}^{3)}\right. \\
5.000-10.000 \\
>10.000\end{array}$ & $\begin{array}{l}15(60) \\
57(75)\end{array}$ & $\begin{array}{l}10(40) \\
19(25)\end{array}$ & 0,237 \\
\hline $\begin{array}{l}\text { Troponin } \mathrm{I}(\mathrm{ng} / \mathrm{mL}) \\
\quad<0,1 \\
>0,1\end{array}$ & $\begin{array}{c}17(94.4) \\
3(100)\end{array}$ & $\begin{array}{l}1(5.6) \\
0(0.0)\end{array}$ & 1.000 \\
\hline $\begin{array}{l}\text { CK-MB }(\mu / \mathrm{L}) \\
\quad<24 \\
\quad>24\end{array}$ & $\begin{array}{c}4(100) \\
16(94.1)\end{array}$ & $\begin{array}{l}0(0.0) \\
1(5.9)\end{array}$ & 1.000 \\
\hline $\begin{array}{l}\text { SGOT }(\mu / \mathrm{L}) \\
\quad<31 \\
\quad>31\end{array}$ & $\begin{array}{c}5(83.3) \\
6(75)\end{array}$ & $\begin{array}{c}1(16.7) \\
2(25)\end{array}$ & 1.000 \\
\hline $\begin{array}{l}\text { SGPT }(\mu / \mathrm{L}) \\
\quad<34 \\
\quad>34\end{array}$ & $\begin{array}{l}4(80) \\
6(75)\end{array}$ & $\begin{array}{l}1(20) \\
2(25)\end{array}$ & 1.000 \\
\hline
\end{tabular}


Hasil analisis hubungan antara karakteristik klinis (lama sakit sebelum masuk rumah sakit, letak membran, demam, nyeri tenggorok, suara parau, bullneck, derajat difteri) dan terjadinya miokarditis melalui uji statistik chi-square menunjukkan p>0,05 pada $\mathrm{CI}=95 \%$ sehingga tidak signifikan secara statistik. Hal ini menunjukkan bahwa pada tingkat kemaknaan 95\% tidak terdapat hubungan antara lama sakit sebelum masuk rumah sakit, letak membran, demam, nyeri tenggorok, suara parau, dan bull neck dengan terjadinya miokarditis pada anak difteri.

Sementara pada variabel stridor diperoleh hasil p $<0,05$ pada $C I=95 \%$ sehingga signifikan secara statistik. Hal ini menunjukkan bahwa pada tingkat kemaknaan 95\% terdapat hubungan antara stridor dengan terjadinya miokarditis pada anak difteri.

Hasil analisis hubungan antara karakteristik laboratoris (jumlah leukosit, troponin I, CK-MB, SGOT dan SGPT) dan terjadinya miokarditis melalui uji statistik chi-square menunjukkan p $>0,05$ pada CI $=95 \%$ sehingga tidak terdapat hubungan signifikan antara keduanya. Hal ini menunjukkan bahwa pada tingkat kemaknaan 95\% tidak terdapat hubungan antara kadar leukosit, troponin I, CK-MB, SGOT dan SGPT dengan terjadinya miokarditis pada anak difteri.

\section{Pembahasan}

Berdasarkan temuan kami diketahui bahwa insiden lebih tinggi terjadi pada perempuan $(51,2 \%)$ dibanding laki -laki $(48,5 \%)$. Hal ini selaras dengan penelitian sebelumnya oleh Gundam $\mathrm{dkk}^{10}$ yang melaporkan bahwa persentase pasien laki-laki (51\%) lebih tinggi dibandingkan perempuan (49\%). Sebaliknya, Meera dan Rajarao ${ }^{11}$ melaporkan lebih banyak insiden pada perempuan $(60 \%)$ lebih banyak dibandingkan dengan laki-laki (40\%). Sebaran usia tertinggi 5-9 (34,7\%) tahun dan terendah di bawah $1(1 \%)$ tahun. Rerata usia subyek adalah 9,5 tahun dengan usia paling muda 8 bulan dan usia tertua 17 tahun 10 bulan. Hasil penelitian ini sejalan dengan beberapa penelitian lainnya, antara lain, penelitian oleh Panamonta $\mathrm{dkk}^{12}$ dan Rapolu $\mathrm{dkk}^{13}$ yang melaporkan bahwa insiden tertinggi kasus difteri pada usia 5-10 tahun.

Status gizi baik memperoleh persentase tertinggi $(43,6 \%)$, diikuti oleh gizi kurang $(40,6 \%)$, gizi lebih $(10,8 \%)$, obesitas $(5 \%)$, dan terendah gizi overweight
(3,5\%). Tidak jauh berbeda halnya dengan penelitian ini, Nawing $\mathrm{dkk}^{14}$ juga melaporkan status gizi baik $(82,4 \%)$ paling banyak menderita difteri. Kecukupan gizi anak yang baik akan meningkatkan daya tahan terhadap penyakit. Anak kurang gizi akan mudah terkena penyakit, terutama penyakit infeksi. Seperti kita ketahui, bahwa hubungan infeksi dengan status gizi sangat erat, demikian juga sebaliknya. Insiden difteri pada penelitian kami lebih banyak terjadi pada anak dengan gizi baik, tetapi moratility rate dari penelitian ini sangat rendah $(4,16 \%)$, yaitu hanya terjadi 3 kematian dari total 72 pasien miokarditis difteri. Berdasarkan literatur diketahui bahwa kunci pencegahan kematian akibat difteri pada anak adalah perbaikan status gizi secara simultan. ${ }^{15}$

Berdasarkan karakteristik klinis pasien diperoleh hasil bahwa gambaran klinis yang paling sering terjadi adalah letak membran pada tonsil bilateral $(44,6 \%)$, demam $(86,1 \%)$, nyeri tenggorokan $(94,1 \%)$, stridor $(27,7 \%)$, suara parau $(22,8 \%)$, bullneck $(12,9 \%)$, dan difteri derajat sedang $(43,6 \%)$. Sejalan dengan penelitian ini, Gundam $\mathrm{dkk}^{10}$ melaporkan bahwa gambaran klinis yang paling sering dijumpai adalah demam, nyeri tenggorokan, nyeri menelan, bull neck, dan suara serak. Penelitian oleh Kole dkk ${ }^{16}$ melaporkan bahwa gambaran klinis yang paling sering dijumpai adalah nyeri menelan, palpitasi, bull neck, dan demam. Namun begitu, Kole juga melaporkan gambaran klinis yang jarang terjadi adalah stridor, perdarahan pada pseudomembran dan gagal ginjal. Penelitian Meera dan Rajarao ${ }^{11}$ melaporkan seluruh pasien difteri datang dengan demam, nyeri menelan, dan pseudomembran. Laringitis derajat ringan-sedang terjadi pada $67 \%$, kasus rhinorrhea terjadi pada 63\% kasus, limfadenopati dan edema pada leher terdapat pada 33\% kasus. Gambaran obstruksi saluran nafas akut dalam bentuk stridor terjadi pada $9 \%$ kasus. Ratageri $\mathrm{dkk}^{17}$ melaporkan bahwa persentasi klinis yang paling sering terjadi, yaitu pseudomembran, demam, limfadenopati servikal, nyeri tenggorokan, bengkak pada leher, disfagia, bull neck, dan halitosis. Sebaliknya, Meshram $\mathrm{dkk}^{18}$ melaporkan bahwa nyeri tenggorokan merupakan persentase klinis yang paling sering dijumpai $(95,74 \%)$. Menurut derajat keparahan, mayoritas kasus subyek berada pada derajat sedang, yaitu 44 (43,6\%), diikuti oleh derajat ringan $41(40,6 \%)$, dan paling sedikit derajat berat $16(15,8 \%)$. Berbeda dengan penelitian oleh Arya $\mathrm{dkk}^{3}$ di India yang melaporkan bahwa data kasus paling banyak adalah derajat ringan $(62,3 \%)$ 
kemudian diikuti derajat sedang $2(2,1) \%$ dan paling sedikit derajat berat $(15,8) \%$.

Karakteristik laboratoris yang paling sering terjadi yaitu peningkatan jumlah leukosit di atas 10.000/ $\mathrm{mm}^{3}$ yang didapatkan pada 76 subyek penelitian $(75,2 \%)$. Sementara karakteristik lainnya, seperti kadar SGOT, troponin I, dan CK-MB pada umumnya tidak mengalami peningkatan. Hal tersebut dikarenakan tidak semua subyek penelitian dilakukan pemeriksaan SGOT, troponin I, dan CK-MB. Akibatnya, ketika dilakukan penilaian secara statistik tidak dijumpai hasil yang bermakna. Havaldar $\mathrm{dkk}^{24}$ melaporkan bahwa leukositosis dan kadar SGOT yang tinggi telah menjadi fatality predictor pada pasien dengan miokarditis difteri. Peningkatan enzim hati sangat bervariasi dalam beberapa penelitian sebelumnya, hal ini terjadi karena variasi dalam peningkatan enzim hati tergantung pada waktu pengambilan sampel dan juga pada tingkat keparahan penyakit pasien. ${ }^{19}$ Wang $\mathrm{dkk}^{21}$ melaporkan bahwa pada pasien dengan miokarditis, kadar CK-MB dan troponin I keduanya mengikuti pola perubahan yang konsisten, yaitu meningkat pada tahap akut penyakit, tetapi kembali normal setelah pemulihan.

Kultur positif ditemukan pada 34 kasus, sedangkan hasil negatif pada 33 kasus, dan 34 subyek lainnya tidak didapatkan hasil swab. Dari hasil positif tersebut, $44,1 \%$ di antaranya adalah tipe gravis, tipe mitis $38,2 \%$, dan tipe intermediat $11,7 \%$. Hal ini dapat dimengerti bahwa pengumpulan sampel dari penelitian ini terjadi saat terjadi epidemi difteri dan diperoleh hasil bahwa terbanyak adalah tipe gravis. Hasil penelitian kami sesuai dengan literatur bahwa pada saat epidemi dapat ditemukan tingkat karier sebesar $25-40 \%$ dari penduduk dengan pola kuman $C$. diphtheriae dari tipe gravis. Saat tidak terjadi epidemi, maka ditemukan tingkat karier sebesar 0,5-1,2\% dari penduduk dengan pola kuman $C$. diphtheriae dari tipe mitis. Penelitian oleh Mutahhar $\mathrm{dkk}^{22}$ melaporkan bahwa galur $C$. diphtheriae mayoritas yang ditemukan adalah C. diphtheriae mitis (90\%), sedangkan sisanya merupakan galur gravis dan tidak ditemukan galur intermediat ataupun belfanti.

Uji bivariat terhadap variabel lama sakit sebelum masuk rumah sakit, letak membran, demam, nyeri tenggorokan, suara parau, bullneck dan derajat difteri terhadap miokarditis difteri menunjukkan hubungan antara stridor dengan terjadinya miokarditis pada anak pasien difteri. Adapun hasil penelitian ini sesuai dengan penelitian Kneen $\mathrm{dkk}^{23}$ di Vietnam yang melaporkan hasil bahwa pasien dengan nyeri tenggorokan, stridor, suara serak, bullneck dan bengkak pada wajah atau leher memiliki hubungan dengan terjadinya miokarditis, yang merupakan penyebab utama perburukan prognosis.

Hasil analisis hubungan antara karakteristik laboratoris dan terjadinya miokarditis menunjukkan tidak terdapat hubungan antara jumlah leukosit, troponin I, CK-MB, SGOT, dan SGPT terhadap terjadinya miokarditis difteri. Hal tersebut berbeda dengan penelitian Havaldar $\mathrm{dkk}^{24}$ yang melaporkan bahwa kenaikan kadar leukosit dan SGOT memiliki pengaruh terhadap terjadinya prognosis buruk pada miokarditis difteri. Peningkatan kadar enzim jantung dan SGOT merupakan indikator terbaik terhadap prognosis. Akan tetapi, dari literatur diketahui bahwa SGOT memiliki keterbatasan spesifisitas yang rendah terhadap otot jantung Peningkatan kadar SGOT juga ditemukan pada kerusakan hati, otot skeletal, paru atau ginjal. Tidak ada isoenzim SGOT yang spesifik jantung dan saat ini pemeriksaan isoenzim SGOT sudah jarang digunakan. ${ }^{25}$

Pengukuran CK-MB merupakan biomarker yang tidak kardiospesifik karena juga dapat meningkat secara bermakna pada pasien dengan trauma otot skeletal akut (59\%), penyakit otot kronik (78\%), dan gagal ginjal kronik $(3,8 \%)$. Oleh karena keterbatasannya ini, maka petanda biokimia yang banyak digunakan untuk mendeteksi adanya kerusakan otot jantung adalah troponin jantung ( $T$ atau I). Lakkireddy dkk ${ }^{26}$ dalam penelitiannya melaporkan bahwa troponin I (TnI) dilepaskan pada saat terjadi cedera miokard yang reversibel dan perbaikan fungsi miokardium bergantung pada kadar TnI yang diukur saat fase akut. Dibandingkan dengan troponin T, TnI sangat spesifik terhadap jaringan miokard dan tidak terdeteksi dalam darah orang sehat. Troponin I lebih banyak didapatkan pada otot jantung daripada CK-MB dan sangat akurat dalam mendeteksi kerusakan jantung. Peningkatan TnI terjadi pada kondisi-kondisi, seperti miokarditis, kontusio kardiak dan setelah pembedahan jantung. Adanya TnI dalam serum menunjukkan telah terjadi kerusakan miokard. ${ }^{25}$

Penelitian kami memiliki beberapa keterbatasan, yaitu pemeriksaan SGOT, SGPT, troponin I, dan CK-MB tidak dapat dilakukan pada semua subyek penelitian karena keterbatasan alat dan bahan di rumah sakit tempat penelitian ini dilakukan. Hal tersebut menyebabkan hubungan antara variabel karakteristik 
klinis dengan terjadinya miokarditis difteri tidak dapat dianalisis secara akurat. Oleh karena itu tidak mengherankan apabila hasil dari penelitian kami tidak ada hubungan antara kedua variabel dependen dan independen tersebut. Selain itu, pada variabel klinis, yaitu diperoleh hasil kultur 33,7\% dari total subyek penelitian yang tidak diketahui hasil kulturnya apakah positif ataupun negatif.

\section{Kesimpulan}

Tidak ada hubungan antara variabel karakteristik laboratoris yaitu jumlah leukosit, troponin I, CK-MB, SGOT, dan SGPT serta variabel klinis, seperti lama sakit sebelum masuk rumah sakit, letak membran, demam, nyeri tenggorokan, suara parau, bullneck dan derajat difteri dengan terjadinya miokarditis difteri, sedangkan pada variabel stridor terdapat hubungan dengan terjadinya miokarditis difteri di RSUD Dr. Zainoel Abidin Banda Aceh.

\section{Daftar pustaka}

1. WHO. Diphtheria Reported Cases. 2018 (Diunduh pada 5 Januari 2019). Didapat dari: URL: http:/lapps.who. int/ immunizationmonitoring/globalsummary/timeseries/ tsincidencediphtheria.html.

2. Dinas Kesehatan Provinsi Aceh. Data Difteri 2019 Provinsi Aceh. Banda Aceh: Dinkes Prov Aceh; 2019.

3. Arya P, Maharia MS, Kadela RK, Deepchand. A clinical study of complications of diphtheria. Int J Otorhinolaryngol Head Neck Surg 2019;5:1052-55.

4. Bowles NE, Towbin JA. Childhood myocarditis and dilated cardiomyopathy. Dalam: Cooper LE, penyunting. Myocarditis: from Bench to Bedside. New Jersey: Humana Press; 2003.h.559-87.

5. Varghese MJ, Ramakrishnan S, Kothari SS, Parashar A, Juneja R, Saxena A. Complete heart block due to diphtheritic myocarditis in the present area. Ann Pediatr Cardiol 2013;6:34-8.

6. Sastroasmoro S, Madiyono B. Miokarditis difteri. Dalam: Buku Ajar Kardiologi Anak. Jakarta: Binarupa Aksara; 1994.h.360-5.

7. Skogmar S, Tham J. Severe diphtheria with neurologic and myocardial involvement in a Swedish patient: a case report. BMC Infect Dis 2018;18:359.

8. Besa NC, Coldiron ME, Bakri A, Raji A, Nsuami MJ, Rousseau C dkk. Diphtheria outbreak with high mortality in
Northeastern Nigeria. Epidemiol Infect 2014;142:797-802.

9. Hartoyo E. Difteri pada anak. Sari Pediatri 2018;19:300-6.

10. Gundam BR, Sudarsi RK, Gundam A. Study of cardiac involvement in diphtheria. J Epid Based Med Health 2016;3:3309-19.

11. Meera M, Rajarao M. Diphtheriain Andhra Pradesh - a clinical epidemiological study. Int J Infect Dis 2014;19:74-8.

12. Panamonta M, Chaikitpinyo A, Lumbiganon P, Panamonta O, Auvichayapat N, Wongswadiwat Y dkk. Historical assessment of diphtheritic myocarditis from a hospital in Northeastern Thailand. Asian Biomed 2014;8:475-84.

13. Rapolu K, Parvathareddy KMR, Karumuri S, Polasa S, Thakkar A. Prognostic significance of electrocardiographic changes in diphtheria myocarditis: a cross-sectional study. Int J Clin Med 2014;5:910-15.

14. Nawing HD, Pelupessy NM, Alimadong H, Albar H. Clinical spectrum and outcomes of pediatric diphtheria. Paediatrica Indones 2019;59:38-43.

15. Rusilanti. Menu Sehat untuk balita. Jakarta: Kawan Pustaka; 2006; h.12.

16. Kole A, Roy R, Kar S. Cardiac involvement in diphtheria: study from a tertiary referral infectious disease hospital. Ann Trop Med Pub Health 2012;5:302-6.

17. Ratageri VH, Bhanu PJ, Shivanand I, Wari P. Diphtheria: time to introspect our immunization practices. Immunol ResTher J 2017; 1:112.

18. Meshram RM, Patil A. Clinical profile and outcome of diphtheria in central India: a retrospective observationalstudy. Int J Contemp Pediatr 2018;5:1600-5.

19. Arya P, Maharia MS, Kadela RK, Deepchand. A clinical study of complica-tions of diphtheria. Int J Otorhinolaryngol Head Neck Surg 2019;5:1052-55.

20. Rashid A, Rasool N, Ajaz S, Wani MI. Clinical profile and predictors of mortality of myocarditis in tertiary care hospital. Int J Sci Study 2017;5:242-5.

21. Wang H, Liu S, Xing YL, Chen R, Yu XY. The limitation of $\mathrm{MB}$ isoenzyme of creatine kinase mass in assess myocardial injury with muscular disease. Zhongguo Wei Zhong Bing Ji Jiu Yi Xue 2011;23:723-6.

22. Mutahhar A, Puspitasari D, Husada D, Kartina L, Basuki PS, Moejito I. Sensitivity of erythromycin against toxigenic strain of corynebacterium diphtheriae. Indones J Trop Infect Dis 2020;8:24-29.

23. Kneen R, Dung N, Solomon T, Giao PN, Parry CM, Hua NTT dkk. Clinical features and predictors of diphtheritic cardiomyopathy in Vietnamese Children. Clin Infect Dis 2004;39:1591-8.

24. Havaldar P, Sankpal M, Doddannavar R. Diphtheric myocarditis : clinical and laboratory parameters of prognosis 
Tita Menawati Liansyah dkk: Hubungan karakteristik klinis dan laboratoris terhadap kejadian miokarditis difteri

and fatal outcome. Ann Trop Pediatr 2000;20:209-15.

25. Samsu N, Sargowo D. Sensitivitas dan spesifisitas troponin T dan I pada diagnosis infark miokard akut. Maj Kedokt Indones 2007;57:363-72.
26. Lakkireddya DR, Kondurb AK, Chediakb EJ, Naira CK, Khan IA. Cardiac troponin I release in non-ischemic reversible myocardial injury from acute diphtheric myocarditis. Int J Cardiol 2005;98:351-4. 